\title{
Canada's Skilled Immigration System
} Increasingly Draws Talent from the United States

CSET Data Brief

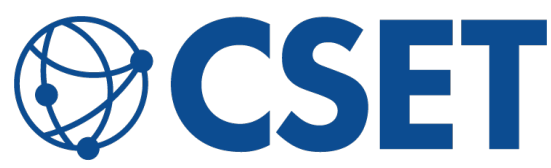

\section{AUTHOR}

Zachary Arnold 


\section{Executive Summary}

The number of U.S. residents who advanced through Express Entry, Canada's flagship skilled immigration program, rose 75\% between 2017 and 2019, a much faster rate of growth than for other countries. This growth was entirely due to successful submissions from U.S. noncitizens, which rose at least $128 \%$ during this period. In total, from 2017 to 2019 , more than 20,000 noncitizen U.S. residents sought and received invitations to apply for permanent residence in Canada through Express Entry. Analysis of this data suggests that skilled foreign-born workers may be leaving the United States for Canada in increasing numbers.

\section{Context}

Governments around the world are competing to attract talent from abroad, and many have set their sights on the United States - in part because they think U.S. immigration policy is driving skilled foreign-born workers away. ${ }^{1}$ Canada arguably leads this competition. In recent years, the Canadian government developed a simpler and more generous immigration system for skilled workers, nurtured cutting-edge tech companies capable of drawing talent from around the world, and even set up billboards in Silicon Valley encouraging immigrant tech workers to relocate north. ${ }^{2}$

Given these efforts and close geographic and cultural ties, Canada is uniquely well positioned to attract talent away from the United States. ${ }^{3}$ But so far, the evidence that skilled workers are now avoiding or leaving the country in large numbers has mostly been anecdotal. ${ }^{4}$ At least before the COVID-19 pandemic, key U.S. immigration pathways such as the $\mathrm{H}-1 \mathrm{~B}$ visa and employment-based green cards remained oversubscribed, and large majorities of foreign-born STEM PhD students at American universities hoped to stay in the United States after graduating. ${ }^{5}$

At the same time, scattered but worrying signs have indicated that the situation may be changing. For example, the number of foreign STEM students studying in the United States has fallen, and growth in the STEM Optional Practical Training work program for international students has slowed considerably. ${ }^{6}$ Now, new data from Canada's flagship skilled immigration program provide further evidence that America's foreign-born talent base may be eroding. 


\section{Data}

Express Entry is the main intake system for skilled foreigners seeking permanent residence in Canada. Express Entry candidates are scored on criteria including but not limited to work experience, education, age, language proficiency, and family ties to Canada. ${ }^{7}$ Those scoring above a specified cutoff receive "invitations to apply" (ITAs) for permanent residence. ${ }^{8}$

Canada's immigration ministry recently published updated Express Entry statistics for calendar years 2017, 2018 and 2019. ${ }^{9}$ These statistics show that rising numbers of U.S. residents, most of whom are not U.S. citizens, are successfully pursuing invitations to resettle permanently in Canada.

As shown in Table 1, about 26,000 U.S. residents received ITAs between 2017 and $2019 .{ }^{10}$ However, only 5,411 U.S. citizens received ITAs. The number of U.S. residents receiving ITAs rose $75 \%$ between 2017 and 2019, but the number who were U.S. citizens actually declined.

Table 1. Express Entry invitations to apply for Canadian permanent residence, 2017-2019

\begin{tabular}{|l|l|l|l|l|l|l|l|l|}
\hline \multicolumn{2}{|l|}{2017} & \multicolumn{2}{l|}{2018} & \multicolumn{2}{l|}{2019} & $\begin{array}{l}\text { Total } \\
2017- \\
2019\end{array}$ & $\begin{array}{l}\text { Growth } \\
2017- \\
2019\end{array}$ \\
\hline $\begin{array}{l}\text { Total Express Entry } \\
\text { invitations issued }\end{array}$ & 86,022 & $100 \%$ & 89,800 & $100 \%$ & 85,300 & $100 \%$ & 261,122 & $-1 \%$ \\
\hline $\begin{array}{l}\text { Invitations issued to } \\
\text { U.S. residents (R) }\end{array}$ & 5,829 & $6.8 \%$ & 9,981 & $11.1 \%$ & 10,185 & $11.9 \%$ & 25,995 & $75 \%$ \\
\hline $\begin{array}{l}\text { Invitations issued to } \\
\text { U.S. citizens (C) }\end{array}$ & 2,047 & $2.4 \%$ & 1,803 & $2.0 \%$ & 1,561 & $1.8 \%$ & 5,411 & $-24 \%$ \\
\hline $\begin{array}{l}\text { Minimum } \\
\text { invitations issued to } \\
\begin{array}{l}\text { U.S. resident } \\
\text { noncitizens (R-C) }\end{array}\end{array}$ & 3,782 & $4.4 \%$ & 8,178 & $9.1 \%$ & 8,624 & $10.1 \%$ & 20,584 & $128 \%$ \\
\hline
\end{tabular}

Source: Express Entry Year-End Report 2019 (first three rows). CSET's calculations in the final row assume that $100 \%$ of U.S. citizen ITA recipients were also U.S. residents. 
The recently released data doesn't include the number of invitations issued to noncitizen residents of the United States. In the last row of Table 1, we calculate the minimum possible value for this number by assuming that every U.S. citizen who received an ITA was also a U.S. resident. ${ }^{11}$ Under this assumption, 8,624 U.S. residents who were not U.S. citizens were selected to apply for permanent residence in Canada in 2019 - an estimated increase of $128 \%$ from 2017 . In total, over 20,000 noncitizen U.S. residents advanced through Express Entry between 2017 and 2019.

Notably, ITAs issued to U.S. residents grew much faster during this period than those granted to residents of other countries, as shown in Table 2. U.S. residents' rate of growth outpaced every other country in the top ten other than Morocco. Although a growth rate specifically for U.S. noncitizen residents is not reported, because ITAs granted to U.S. citizens fell during the same period, noncitizens must have accounted for all of this growth. ${ }^{12}$

Table 2. Express Entry invitations to apply for Canadian permanent residence, 2017-2019, by recipient's country of residence

\begin{tabular}{|l|r|r|r|r|}
\hline & \multicolumn{2}{|l|}{2017} & 2019 & Growth 2017-2019 \\
\hline All & 86,022 & 89,800 & 85,300 & $-1 \%$ \\
\hline Canada & 42,233 & 39,936 & 40,550 & $-4 \%$ \\
\hline India & 14,910 & 17,636 & 14,926 & $0 \%$ \\
\hline United States & 5,829 & 9,981 & 10,185 & $75 \%$ \\
\hline Nigeria & 2,910 & 3,724 & 3,819 & $31 \%$ \\
\hline UAE & 2,436 & 2,029 & 1,708 & $-30 \%$ \\
\hline Pakistan & 1,331 & 1,365 & 1,180 & $-11 \%$ \\
\hline Morocco & 255 & 585 & 860 & $18 \%$ \\
\hline Australia & 673 & 831 & 791 & $-22 \%$ \\
\hline China & 985 & 871 & 768 & $-55 \%$ \\
\hline UK & 1,560 & 1,186 & 699 & $-24 \%$ \\
\hline Other & 12,900 & 11,656 & 9,814 & \\
\hline
\end{tabular}

Source: Express Entry Year-End Report 2019 


\section{Implications}

More U.S. residents are advancing through the Express Entry program. That means either more U.S. residents are seeking permanent residence in Canada, or U.S. residents who are seeking permanent residence in Canada are becoming more qualified according to the Express Entry scoring criteria, or both. ${ }^{13}$ It's not clear from the recently published data which is the case, but none of these possibilities is encouraging for the United States. In addition, the fact that U.S. noncitizens are driving the trends explored in this paper strongly suggests the combination of Canadian recruitment and increasingly restrictive American immigration policy is playing a role in pushing talent north. ${ }^{14}$

If skilled workers are leaving the United States, Canada is not the only nation that stands to benefit. Many other countries have the resources and political will to attract globally mobile talent. ${ }^{15}$ If Canada succeeds in recruiting skilled workers from the United States, other countries could too. To avoid falling behind in the global competition for talent, the United States should invest more resources in STEM research and education, lift outdated and counterproductive immigration restrictions, and build new pathways for talented individuals to live, work and innovate in America.

\section{Acknowledgments}

Thanks to Tina Huang, Igor Mikolic-Torreira, Dewey Murdick, Remco Zwetsloot, and especially Stephanie Fraser for helpful comments.

\section{(c) $(1) \Theta$}

(c) 2020 by the Center for Security and Emerging Technology. This work is licensed under a Creative Commons Attribution-Non Commercial 4.0 International License.

To view a copy of this license, visit https://creativecommons.org/licenses/by-nc/4.0/. 


\section{Endnotes}

1 See, e.g., Tina Huang and Zachary Arnold, "Immigration Policy and the Global Competition for Al Talent" (Center for Security and Emerging Technology, June 2020), https://cset.georgetown.edu/wp-content/uploads/CSET-Immigration-Policy-and-theGlobal-Competition-for-Al-Talent-1.pdf; Catherine Wong, "Tough US immigration policy could be the key to China winning technology race, says top Al investor," South China Morning Post, October 30, 2019, https://www.scmp.com/news/china/diplomacy/article/3035546/tough-us-immigrationpolicy-could-be-key-china-winning; Michael Stothard, "European tech has a message for President Trump: 'Send your immigrants to us,'" Sifted, June 24, 2020, https://sifted.eu/articles/trump-immigrant-visa-europe/.

2 Somini Sengupta, "Countries Seek Entrepreneurs from Silicon Valley," New York Times, June 6, 2013, https://www.nytimes.com/2013/06/06/technology/wishing-you-andyour-start-up-were-here.html.

3 See, e.g., Joel Rose, "Canada Wins, U.S. Loses In Global Fight For High-Tech Workers," NPR, January 27, 2020, https://www.npr.org/2020/01/27/799402801/canadawins-u-s-loses-in-global-fight-for-high-tech-workers; Sengupta, "Countries Seek Entrepreneurs from Silicon Valley."

${ }^{4}$ See, e.g., discussion and sources cited in Zachary Arnold et al., "Immigration Policy and the U.S. Al Sector" (Center for Security and Emerging Technology, September 2019), 3-4, https://cset.georgetown.edu/wp-content/uploads/CSET-Immigration-Policy-and-theGlobal-Competition-for-Al-Talent-1.pdf.

${ }^{5}$ Remco Zwetsloot et al., "Trends in U.S. Intention-to-Stay Rates of International Ph.D. Graduates Across Nationality and STEM Fields" (Center for Security and Emerging Technology, April 2020), https://cset.georgetown.edu/wp-content/uploads/CSET-Trendsin-U.S.-Intention-to-Stay-Rates.pdf; see also Remco Zwetsloot et al., "Keeping Top Al Talent in the United States" (Center for Security and Emerging Technology, December 2019), https://cset.georgetown.edu/wp-content/uploads/Keeping-Top-Al-Talent-in-the-UnitedStates.pdf.

${ }^{6}$ Kathleen Struck, "Fewer Foreign Students Enrolling in US College and Universities," Voice of America, November 18, 2019, https://www.voanews.com/student-union/fewerforeign-students-enrolling-us-college-and-universities; Neil G. Ruiz and Abby Budiman, "Number of Foreign College Graduates Staying in US to Work Climbed Again in 2017, but Growth Has Slowed" (Pew Research Center, July 25, 2018), https://www.pewresearch.org/fact-tank/2018/07/25/number-of-foreign-collegegraduates-staying-in-u-s-to-work-climbed-again-in-2017-but-growth-has-slowed/. There is some evidence that Indian graduate students, who comprise a large share of foreign STEM graduate students in the United States, are increasingly choosing Canada over the United States. See "Analysis of International Student Data for the 2018-2019 Academic Year" (National Foundation for American Policy, June 2020), https://nfap.com/wp- 
content/uploads/2020/06/Analysis-of-International-Student-Data.NFAP-PolicyBrief.June-2020-3.pdf.

${ }^{7}$ This is known as the Comprehensive Ranking System (CRS). See "Comprehensive Ranking System (CRS) Criteria - Express Entry," Immigration, Refugees and Citizenship Canada, August 12, 2019, https://www.canada.ca/en/immigration-refugeescitizenship/services/immigrate-canada/express-entry/eligibility/criteria-comprehensiveranking-system/grid.html.

8 "Express Entry Year-End Report 2019" (Immigration, Refugees and Citizenship Canada, June 2020), 5,

https://www.canada.ca/content/dam/ircc/migration/ircc/english/pdf/pub/2019-eereport-pdfversion-eng.pdf (hereinafter "Express Entry 2019 Report"). The cutoff score changes periodically, depending on the applicant pool. It's not clear from available data how many invitees ultimately move to Canada. The proportion is probably high, though. Preparing for and participating in the Express Entry process is not trivial, so on the whole, those who go through it and score highly are likely to be seriously considering an eventual move. Also, many recipients already have job offers in Canada when they go through Express Entry, which can earn them extra points. See Immigration, Refugees and Citizenship Canada, "Comprehensive Ranking System (CRS) Criteria - Express Entry."

${ }^{9}$ Express Entry began processing candidates in 2015. However, we omit 2015 and 2016 from our analysis. Statistics from these years may not be fully comparable to later numbers, since the program was new, operating at a limited scale, and working through a backlog of temporary Canadian residents admitted under prior programs. The selection criteria were also revised in late 2016. See Express Entry Year-End Report 2016" (Immigration, Refugees and Citizenship Canada, 2017), 4-5, 14, https://www.canada.ca/content/dam/ircc/migration/ircc/english/pdf/pub/ee-2016eng.pdf.

${ }^{10}$ All figures in Table 1 are derived from Express Entry 2019 Report, Tables 27 and 30 (pp. 22-23).

${ }^{11}$ If some of the U.S. citizen ITA recipients lived outside the United States, there would have to be more U.S.-resident noncitizen recipients in order to reach the observed number of U.S. resident applicants. Therefore, our assumption produces a lower bound for the number of ITAs granted to U.S.-resident noncitizens.

12 Indian citizens received nearly half of all ITAs issued in 2019, and may account for a large share of the U.S.-resident noncitizens who received ITAs. See Express Entry 2019 Report at 23; see generally Stuart Anderson, "Indians Immigrating To Canada At An Astonishing Rate," Forbes, February 3, 2020, https://www.forbes.com/sites/stuartanderson/2020/02/03/indians-immigrating-tocanada-at-an-astonishing-rate/.

${ }^{13}$ Canada's efficient temporary work permit system, overhauled in 2017, helps Express Entry participants score higher by quickly connecting immigrants to jobs in Canada before 
they apply for permanent residence. These Canadian jobs boost the participants' Express Entry scores. See "Government of Canada launches the Global Skills Strategy," Immigration, Refugees and Citizenship Canada, June 12, 2017,

https://www.canada.ca/en/immigration-refugees-

citizenship/news/2017/06/government of canadalaunchestheglobalskillsstrategy.html.

${ }^{14}$ See generally Arnold et al., Immigration Policy and the U.S. AI Sector"; Zwetsloot et al., "Keeping Top Al Talent in the United States."

${ }^{15}$ See, e.g., Meng Jing, "China's top talent now wants to work for rising domestic tech stars, not big brand multinationals," South China Morning Post, June 21, 2019,

https://www.scmp.com/tech/policy/article/3015377/chinas-top-talent-now-wantswork-rising-domestic-tech-stars-not-big; Stothard, "European tech has a message for President Trump: 'Send your immigrants to us'"; see generally Huang and Arnold, "Immigration Policy and the Global Competition for Al Talent." 